\title{
VARIABLE ON-TIME CONTROL SCHEME TO ACHIEVE HIGH EFFICIENCY FOR AC/DC BORDER LINE CURRENT MODE BUCK CONVERTER
}

Abdul Hakeem Memon
IICT, Mehran UET, Jamshoro, Sindh, (Pakistan).
E-mail: hakeem.memon@faculty.muet.edu.pk
ORCID: https://orcid.org/0000-0001-8545-3823

Asif Zahoor Shaikh

IICT, Mehran UET, Jamshoro, Sindh, (Pakistan).

E-mail: asifzahoorshaikh@gmail.com

ORCID: https://orcid.org/0000-0003-2999-6772

Zubair Ahmed Memon

IICT, Mehran UET, Jamshoro, Sindh, (Pakistan).

E-mail: zubair.memon@faculty.muet.edu.pk

ORCID: https://orcid.org/0000-0001-5967-3152

Anwar Ahmed Memon

IICT, Mehran UET, Jamshoro, Sindh, (Pakistan).

E-mail: anwar.memon@faculty.muet.edu.pk ORCID: https://orcid.org/0000-0001-6600-204X

\section{Citación sugerida:}

Memon, A. H., Shaikh, A. Z., Memon, Z. A., y Memon, A. A. (2022). Variable on-time control scheme to achieve high efficiency for AC/DC border line current mode buck converter. $3 C$ Tecnología. Glosas de innovación aplicadas a la pyme, Edición Especial, (febrero 2022), 181-195. https://doi. org/10.17993/3ctecno.2022.specialissue9.181-195 


\section{ABSTRACT}

The Buck power factor improvement converter (BPFIC) is much better topology because of having advantages like less inrush current, less voltage gain ratio, gives less voltage output ripple and steps down the voltage even with high input voltage, protection from short circuit and its single active switch operation makes it attractive. However borderline current mode (BCM) operated with fixed on-time control technique (FOCT) results in its low efficiency. The main reason of low efficiency is due to high conduction and switching losses which occur due to high peak and rms inductor current. In this paper, varying on-time control technique (VOCT) has been implemented that reduces the peak value of current which results in improved efficiency. In the proposed research, work is related to BPFIC operating in BCM because BCM has many advantages like no reverse recovery of diode, and zero current turning off the switch. To verify the effectiveness of proposed control technique, comparative analysis is obtained between both the two control techniques using SABER SIMULATOR. It is found that VOCT improves the converter's efficiency compared to FOCT.

\section{KEYWORDS}

Buck Power Factor Improvement Converter (BPFIC), Borderline Current Mode (BCM), Fixed On-Time Control Technique (FOCT), Varying On-Time Control Technique (VOCT), Saber Simulation. 


\section{INTRODUCTION}

The increasing need of electronic devices (requires AC to DC conversion) have resulted in harmonic content produced by non-linear elements (diodes and thyristors) of electronic devices connected to AC supply system should be in such limit that it meets regulatory standard. This requirement is fulfilled by using active power factor improvement (PFI) circuits that shape the input phase current to be sinusoidal in nature and in phase with input phase voltages. The combined effect of non-linear loads results in problem of serious harmonic distortion in electrical distribution system and its result is poor Power Factor $(\mathrm{PF})$ and power quality, voltage distortion and low efficiency (Azazi et al., 2010). PFI can be categorized into active and passive types. Compared with a Passive Power Factor Improvement Converters (PFIG), an active PFIC can achieve a high PF (Nagaraju \& Krishnaveni, 2017). The PFIC are being widely used in ac $-\mathrm{dc}$ power conversions to get power factor near to unity and to reduce harmonic distortion so as to meet the standards like IEC61000-3-2 and IEEE 519 (Yao et al., 2011).

Amongst PFIC, buck Power Factor Improvement Converter (BPFIC) is much better topology because of having advantages like less inrush current, less voltage gain ratio, gives less voltage output ripple and steps down the voltage even with high input voltage, protection from short circuit and its single active switch operation makes it attractive. However, because of dead zone in the input current of (BPFIC) has resulted in poor PF and other power quality issues

For enhancing the performance of BPFIC, different authors have proposed several control techniques (Endo, Yamashita, \& Sugiura, 1992; Memon et al., 2021).

In this paper, Variable On-Time Technique (VOCT) is implemented to reduce the conduction and switching losses occurred in borderline current mode BPFIC caused by peak and rms value of inductor current.

This paper is divided into six sections. First section gives detailed analysis of traditional BPFIC. In, second section VOCT is implemented to improve converter's efficiency. Third section represents loss analysis caused by conduction and switching losses. Fourth section 
shows simulation verification to confirm the effectiveness of proposed control technique. In last section conclusion is discussed.

\section{METHODOLOGY}

The research methodology is based on:

1. Mathematical analysis of the operating principle of the control schemes for Borderline Current Mode (BCM) Buck Power Factor Improvement Converter (BPFIG) for FOCT with the help of MATHCAD converter.

2. Introducing the Varying On-Time Control Technique (VOCT) to obtain high efficiency.

3. Comparative analysis of the converter for FOCT and VOCT strategy.

4. Developing the simulation model of BCM Buck converter with the help of SABER software.

5. Confirming the results.

\subsection{WORKING ANALYSIS OF TRADITIONALLY USED BCM BPFIC}

Figure 1 shows the circuit of Buck Power Factor Improvement Converter (BPFIG) that can be operated in borderline current mode (BCM). The working of the BPFIC will be analyzed in detail with the help of equations in order to find out the expression of fixed on-time technique (FOCT).

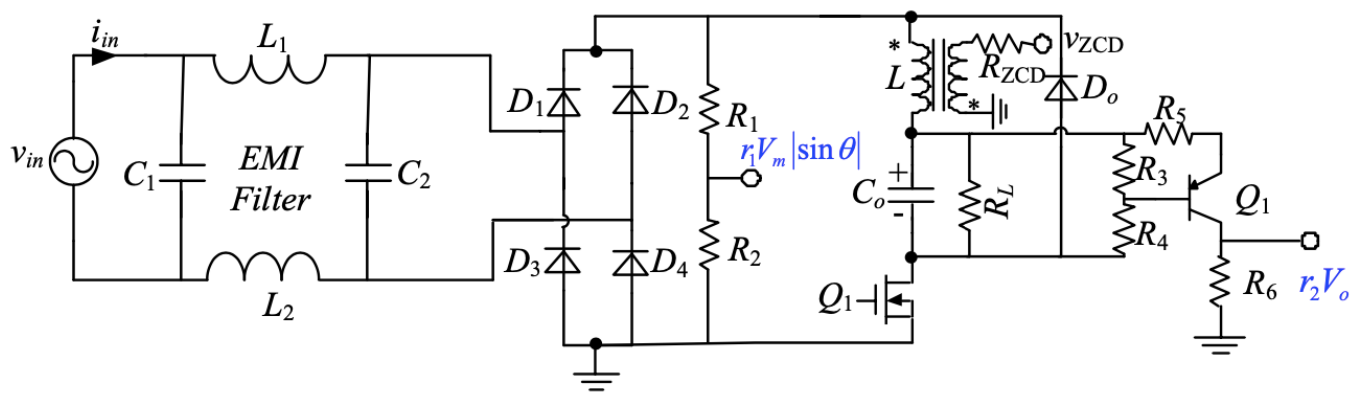

Figure 1. Circuit Diagram of BPFIC.

Source: (Memon et al., 2021). 
The instantaneous value of source voltage at the input and output of bridge is expressed as

$$
v_{\text {in_bpfic }}=v_{g}=V_{m} \sin \theta
$$

BPFIC operated with BCM has two switching cycles.

The inductor is charged from supply voltage when the buck switch is $\mathrm{ON}$, as indicated in Figure 2 (First switching cycle).

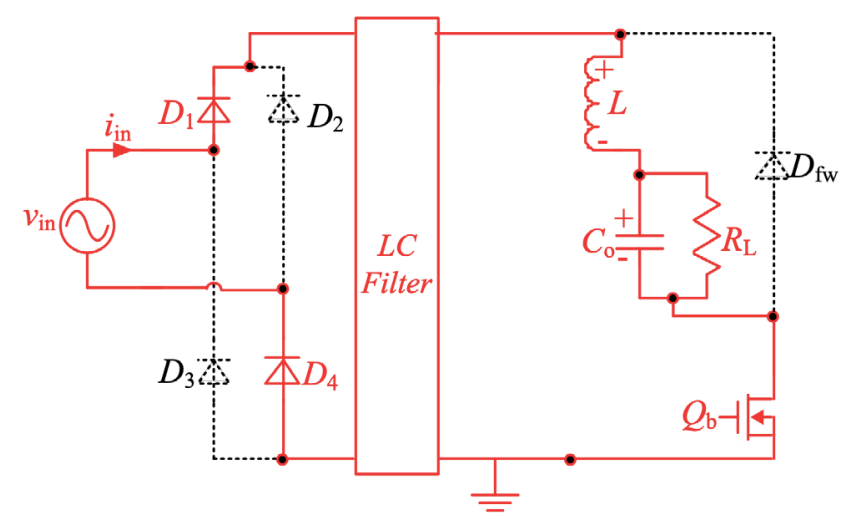

Figure 2. BPFIC when switch is on.

Source: (Memon et al., 2018).

The maximum current flowing through inductor for BPFIC with FOCT is

$$
i_{m_{-} \text {foct }}=t_{\text {on_foct }} \frac{V_{m}|\sin \theta|-V_{o_{-} b p f i c}}{L}
$$

The inductor is discharged through load when the buck switch is OFF, as showed in Figure 3 and the expression is given in (3) (Second switching cycle).

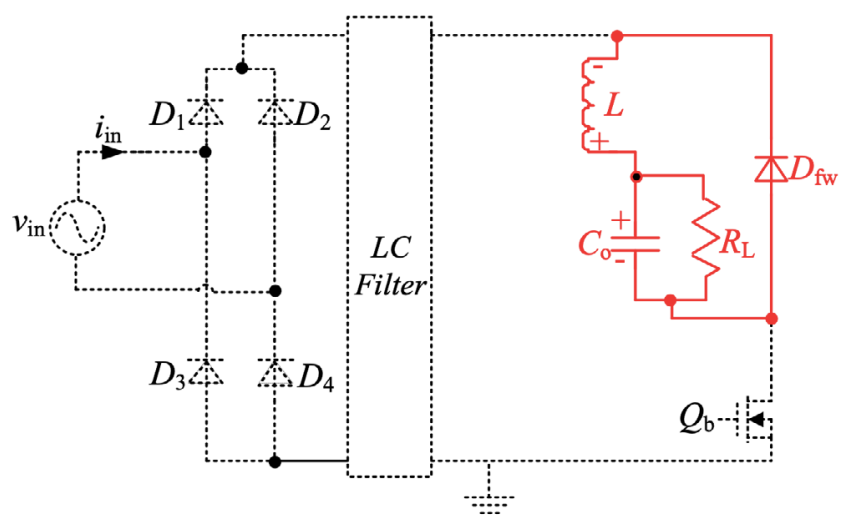

Figure 3. BPFIC when switch is off.

Source: own elaboration. 


$$
i_{m_{-} f o c t}=-\frac{V_{o}}{L} T_{o f f}
$$

The maximum current for charging and discharging is same as per energy conservation. So, following relation is got

$$
t_{\text {off }}=t_{\text {on }_{-} \text {foct }} \frac{V_{m}|\sin \theta|-V_{o_{-} b p f i c}}{V_{o_{-} b p f i c}}
$$

Similarly

$$
t_{s_{-} b p f i c}=t_{\text {on_foct }}+t_{\text {off }}
$$

By substituting (3) into (5) yields

$$
t_{s_{-} b p f i c}=\left(\frac{V_{m}|\sin \theta|}{V_{o_{-} b p f i c}}\right) t_{o n_{-} f o c t}
$$

The average input current for BPFIC with FOCT is calculated as

$$
i_{\text {arg_bpfic }}=i_{\text {avg_bpfic (foct })}=\frac{i_{m_{-} f o c t} t_{\text {on_foct }}}{2 t_{s_{-} b p f i c}}=\frac{t_{\text {on_foct }} V_{o_{-} b p f i c}}{2 L}\left(\frac{V_{m}|\sin \theta|-V_{o_{-} \text {bpfic }}}{V_{m}|\sin \theta|}\right)
$$

From (1) and (7), the input power of the BPFIC with FOGT is given

$$
P_{i n_{-} \text {foct }}=\frac{t_{\text {on_foct }} V_{o_{-} b p f i c}}{2 \pi L} \int_{\theta_{0}}^{\pi-\theta_{0}}\left(V_{m}|\sin \theta|-V_{o_{-} b p f i c}\right) d \theta
$$

The value of $t_{o n_{-} \text {foct }}$ is expressed after supposing $100 \%$ efficiency as

$$
t_{\text {on_foct }}=\frac{2 \pi P_{o} L}{\int_{\theta_{0}}^{\pi-\theta_{0}} V_{o_{-} b p f i c}\left(V_{m}|\sin \theta|-V_{o_{-} b p f i c}\right) d \theta}
$$

\subsection{PROPOSED VOCT FOR BPFIC FOR ENHANCING EFFICIENCY}

For improving the efficiency for the BPFIC, the on-time of buck CMOS in (9) has to change as

$$
t_{\text {on_voct }}=M_{\text {on }} \frac{\left(V_{m}|\sin \theta|\right)^{2}}{V_{o_{-} b p f i c}\left(V_{m}|\sin \theta|-V_{o_{-} b p f i c}\right)}
$$


where $M_{o n}$ is a constant

Replacing (10) into (7), the input current of the BPFIC is

$$
i_{\text {in_voct_bfpic }_{-}}=\frac{V_{m}|\sin \theta|}{2 L} M_{\text {on }}\left(\theta_{0} \leq \theta \leq \pi-\theta_{0}\right)
$$

The input power for BPFIC with VOCT is got as

$$
P_{\text {in_bpfic_voct }}=\frac{1}{\pi} \int_{\theta_{0}}^{\pi-\theta_{0}} \frac{M_{o n}\left(V_{m} \sin \theta\right)^{2}}{2 L} d \theta=P_{o}
$$

Rearranging (12), we get

$$
M_{o n}=\frac{2 \pi L P_{o}}{\int_{\theta_{0}}^{\pi-\theta_{0}}\left(V_{m} \sin \theta\right)^{2} d \theta}
$$

\subsection{EFFICIENCY COMPARISON}

\subsubsection{POWER LOSS DUE TO BRIDGE RECTIFIER}

The power loss due to bridge rectifier in BPFIC with FOCT and VOCT is estimated as

$$
\begin{aligned}
& P_{\text {con_bpfic_bridge(fotc) }}=2 V_{F D} i_{a v g_{-} b p f i c(f o c t)} \\
& P_{\text {con_bpfic_bridge(voct) }}=2 V_{F D} i_{a v g_{-} b p f i c(v o c t)}
\end{aligned}
$$

The value of VFD for GBU 406 is 0.89 .

\subsubsection{CONDUCTED LOSSES BY CMOS (SWITCH)}

The rms current flowing through switch, when it is on is given as

$$
I_{r m s_{-} b p f i c \_Q_{-} o n}=\sqrt{\frac{\int_{\theta_{0}}^{\pi-\theta_{0}} i_{m_{-} b p f i c}^{2} D_{o n} d \theta}{3 \pi}}
$$

The rms current of the off time period can be determined as

$$
I_{r m s_{-} b p f i c_{-} Q_{-} o f f}=\sqrt{\frac{\int_{\theta_{0}}^{\pi-\theta_{0}} i_{m_{-} b p f i c}^{2} D_{o f f} d \theta}{3 \pi}}
$$


The rms current due to switch on and off is calculated as

$$
\begin{aligned}
& I_{r m s_{-} b p f i c_{-} f o c t}=\sqrt{I_{r m s_{-} b p f c_{-} Q_{-} o n}^{2}+I_{r m s\left(Q b_{-} o f f \_c d c c s\right)}^{2}} \\
& I_{r m s_{-} b p f c_{-} v o c t}=\sqrt{\left.I_{r m s_{-} b p f i c_{-} Q_{-} o n}^{2}+I_{r m s\left(Q b_{-} o f f_{-} v o c t\right)}^{2}\right)}
\end{aligned}
$$

The losses due to conduction of switches can be got as

$$
\begin{aligned}
& P_{\text {con_cmos_bpfic_foct }}=I_{r m s_{-} b p f i c c_{-} f o c t}^{2} R_{D S(o n)_{-} S} \\
& P_{c o n_{-} c m o s_{-} b p f i c_{-} v o c t}=I_{r m s_{-} b p f i c_{-} v o c t}^{2} R_{D S(o n)_{-} S}
\end{aligned}
$$

The resistance from drain to source is 0.188 , which is from data sheet of $8 \mathrm{~N} 60$.

\subsubsection{SWITCH OFF LOSSES BY CMOS (SWITCH)}

When the switch is off, the loss of BPFG with FOCT and VOCT is expressed as

$$
\begin{aligned}
& P_{\text {off_cmos_foct }}=\frac{t_{s_{-} b p f i c} t_{f}}{2 \pi} \int_{0}^{\pi} i_{m_{-} f o c t}\left(V_{m} \sin \theta\right) d \theta \\
& P_{\text {off_cmos_voct }}=\frac{t_{s_{-} b p f i c} t_{f}}{2 \pi} \int_{0}^{\pi} i_{m_{-} \text {voct }}\left(V_{m} \sin \theta\right) d \theta
\end{aligned}
$$

$T_{f}$ for $8 \mathrm{~N} 60$ is $12 \mathrm{~ns}$.

\subsubsection{COPPER LOSS OF THE BPFIC' S INDUCTOR}

The inductor's copper loss of BPFIC with FOCT and VOCT is given as

$$
\begin{aligned}
& P_{c u_{-} f o c t}=I_{r m s_{-} b p f i c_{-} f o c t}^{2} R_{c u} \\
& P_{c u_{-} v o c t}=I_{\text {rms_bpfic_foct }}^{2} R_{c u}
\end{aligned}
$$

\subsubsection{CORE LOSS OF BPFIC' S THE INDUCTOR}

The inductor's core loss of BPFIC with FOCT and VOCT is given as

$$
P_{\text {bpfic_core_foct }}=\left[\int_{0}^{\pi} C_{m} f_{s_{-} b p f i c_{-} f o c t}{ }^{x} B_{a c_{-} b p f i c_{-} f o c t}{ }^{y}\left(c t_{0}-c t_{1} T_{a}-c t_{2} T_{a}^{2}\right) d \theta\right] \frac{10^{3} V_{e}}{\pi}
$$




$$
\begin{aligned}
& B_{a c_{-} b p f i c_{-} f o c t}=\frac{i_{m_{-} f o c t} L}{2 N A_{e}} \\
& P_{\text {bpfic_core_ } v o c t}=\left[\int_{0}^{\pi} C_{m} f_{s_{-} b p f i c_{-} f o c t}^{{ }^{x}} B_{a c_{-} b p f i c_{-} \text {voct }}{ }^{y}\left(c t_{0}-c t_{1} T_{a}-c t_{2} T_{a}^{2}\right) d \theta\right] \frac{10^{3} V_{e}}{\pi} \\
& B_{a c_{-} b f f i c_{-} v o c t}=\frac{i_{m_{-} f o c t} L}{2 N A_{e}}
\end{aligned}
$$

The value of core parameters can be found from Memon et al. (2018).

\subsubsection{CONDUCTED LOSS BY FREEWHEELING DIODE}

The conducted losses by freewheeling diode of BPFIC with FOCT and VOCT is got as

$$
\begin{gathered}
P_{b p f i c \_c o n_{-} f r e e w h d i o d e_{-} f o c t}=\frac{V_{F D_{f w}}}{\pi} \int_{0}^{\pi} \frac{i_{m_{-} \text {foct }}}{2} D_{o f f} d \theta \\
P_{\text {bpfic_con_freewhdiode_voct }}=\frac{V_{F D_{f w}}}{\pi} \int_{0}^{\pi} \frac{i_{m_{-} v o c t}}{2} D_{o f f} d \theta
\end{gathered}
$$

The forward voltage drop is 0.669 for MUR 860.

\subsubsection{THE EFFICIENCY COMPARISON}

The efficiency of BCM BPFIC with FOCT and VOCT can be estimated as

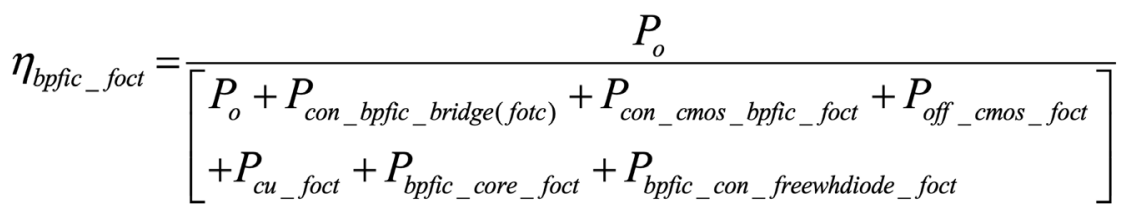

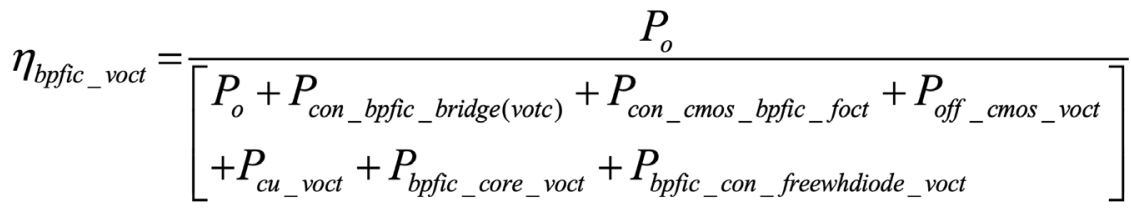


The calculated efficiency of BCM BPFIC with FOGT and VOCT from (14-23) and specification is depicted in Figure 4. It can be observed the efficiency of BPFIC with VOCT is more than FOCT.

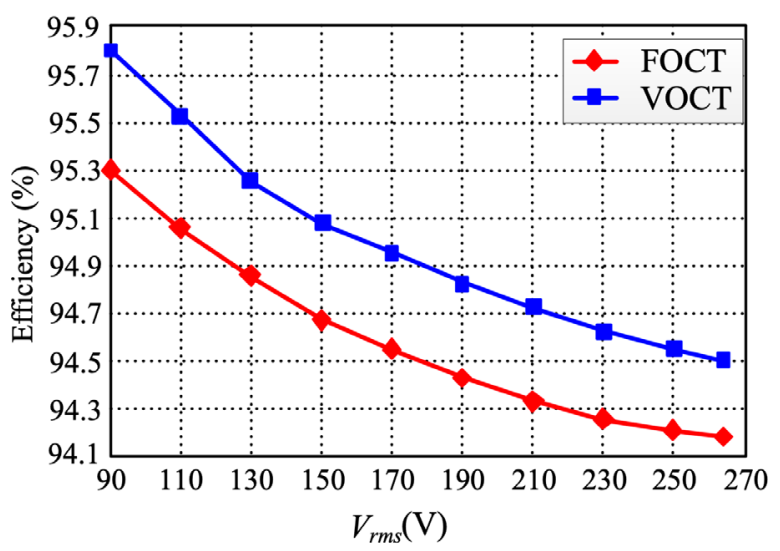

Figure 4. Efficiency at universal input voltage (Mathcad Graph from Eq. (14-23)).

Source: own elaboration.

\section{SIMULATION RESULTS}

In order to verify the effectiveness of VDCT, simulation verification is obtained using MATLAB. The input voltage range is $90-264 \mathrm{VAC}$, and the output is $80 \mathrm{~V}$. For ensuring the current to be in CRM, L6561 IC is used. All the components in the circuit are selected as idea.

In Figure 5, the peak of input current obtained in case of FOCT is more. The current having more peak results in losses that degrades converter's efficiency whereas in Figure 6, the peak of input current obtained in case of VOCT is less which reduces conduction and switching losses hence converter's performance is improved.

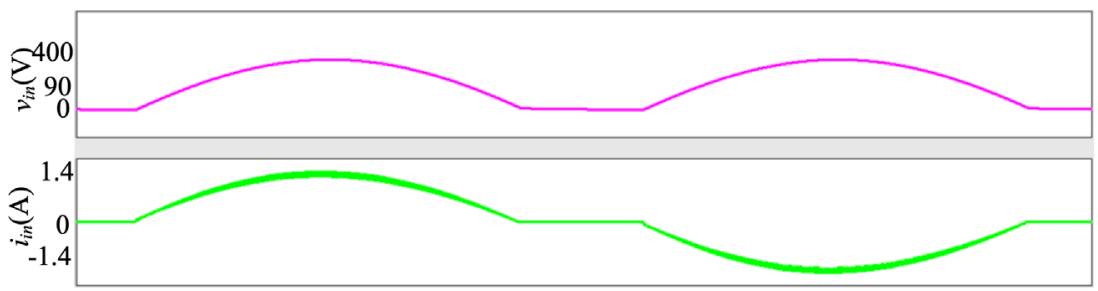

Figure 5. $v_{i n}$, and $i_{i n}$ with FOCT (Simulation waveform).

Source: own elaboration. 


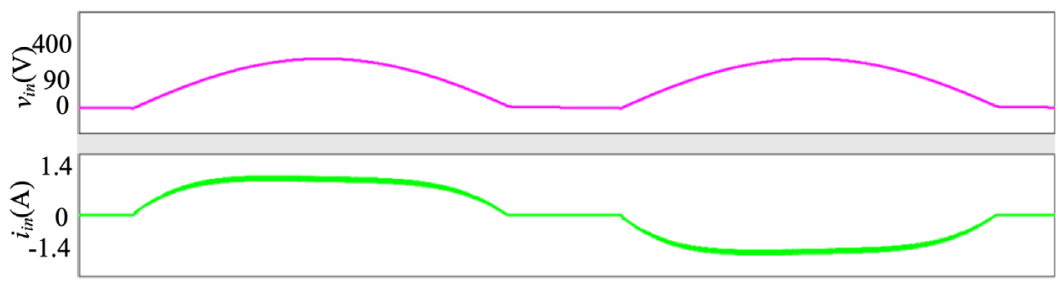

Figure 6. $v_{i n}$, and $i_{\text {in }}$ with VOCT (Simulation waveform).

Source: own elaboration.

\section{CONCLUSIONS}

The Buck Power Factor Improvement Converter (BPFIG) is much better topology because of having many advantages. However Borderline Current Mode (BCM) operated with Fixed On-Time Technique (FOCT) results in its low efficiency. The main reason of low efficiency is due to high conduction and switching losses which occur due to high peak and rms inductor current. In this paper, Varying On-Time Technique (VOCT) has been implemented that reduces the peak value of current which results in improved efficiency.

\section{REFERENCES}

Azazi, H. Z., El-Kholy, E. E., Mahmoud, S. A., \& Shokralla, S. S. (2010). Review of passive and active circuits for power factor correction in single phase, low power AC-DG converters. In Proceedings of the 14th International Middle East Power Systems Conference (MEPCON'10) (p. 217). http://citeseerx.ist.psu.edu/viewdoc/ download?doi=10.1.1.1054.59\&rep=rep $1 \&$ type $=$ pdf

Endo, H., Yamashita, T., \& Sugiura, T. (1992). A high-power-factor buck converter. In PESC'92 Record. 23rd Annual IEEE Power Electronics Specialists Conference (pp. 10711076). IEEE. https://www.semanticscholar.org/paper/A-high-power-factor-buckconverter-Endo-Yamashita/d2e981fa9b793d855da6f572abac2470ab06248b

Erickson, R. W., \& Maksimovic, D. (2007). Fundamentals of power electronics. Springer Science \& Business Media. 
Huber, L., Gang, L., \& Jovanovic, M. M. (2009). Design-oriented analysis and performance evaluation of buck PFC front end. IEEE Transactions on power electronics, 25(1), 85-94. https://doi.org/10.1109/TPEL.2009.2024667

Jang, Y., \& Jovanović, M. M. (2010). Bridgeless high-power-factor buck converter. IEEE Transactions on Power Electronics, 26(2), 602-611. https://doi.org/10.1109/ TPEL.2010.2068060

Ki, S. K., \& Lu, D. D. G. (2012). A high step-down transformerless single-stage singleswitch AC/DG converter. IEEE Transactions on Power Electronics, 28(1), 36-45. https:// doi.org/10.1109/TPEL.2012.2195505

Lamar, D. G., Fernandez, M., Arias, M., Hernando, M. M., \& Sebastian, J. (2012). Tapped-inductor buck HB-LED AC-DC driver operating in boundary conduction mode for replacing incandescent bulb lamps. IEEE Transactions on Power Electronics, 27(10), 4329-4337. https://doi.org/10.1109/TPEL.2012.2190756

Lee, Y. S., Wang, S. J., \& Hui, S. Y. R. (1997). Modeling, analysis, and application of buck converters in discontinuous-input-voltage mode operation. IEEE Transactions on Power Electronics, 12(2), 350-360. https://doi.org/10.1109/63.558762

Liu, X., Wan, Y., He, M., Zhou, Q., \& Meng, X. (2020). Buck-Type Single-Switch Integrated PFC Converter With Low Total Harmonic Distortion. IEEE Transactions on Industrial Electronics, 68(8). https://doi.org/10.1109/TIE.2020.3007121

Memon, A. (2020a). DCM Boost Converter with High Efficiency. Fournal Of Mechanics Of Continua And Mathematical Sciences, spl6. https://doi.org/10.26782/jmcms. spl.6/2020.01.00006

Memon, A. (2020b). Realization Of Unity Power Factor For Ac/Dc Boundary Conduction Mode Flyback Converter With Any Specific Turn's Ratio. Journal Of Mechanics Of Continua And Mathematical Sciences, spl6. https://doi.org/10.26782/jmcms. spl.6/2020.01.00014 
Memon, A. H., \& Yao, K. (2018). UPC strategy and implementation for buck-buck/ boost PF correction converter. IET Power Electronics, 11(5), 884-894. https://doi. org/10.1049/iet-pel.2016.0919

Memon, A. H., Ali, R., \& Memon, Z. A (2021a). Discontinuous Conduction Mode Buck Converter with High Efficiency. 3C Tecnología. Glosas de innovación aplicadas a la pyme. Edición Especial, May 2021, 31-47. https://doi.org/10.17993/3ctecno.2021. specialissue 7.31-47

Memon, A. H., Baloach, M. H., Sahito, A. A., Soomro, A. M., \& Memon, Z. A. (2018). Achieving High Input PF for CRM Buck-Buck/Boost PFC Converter. IEEE Access, 6, 79082-79093. https://doi.org/10.1109/ACGESS.2018.2879804

Memon, A. H., Memon N, \& Memon, Z. A (2021b). Modified Variable On-Time Control Scheme To Realize High Power Factor For AC/DG Integrated Buck-Boost Converter. 3C Tecnología. Glosas de innovación aplicadas a la pyme. Edición Especial, May 2021, 61-75. https://doi.org/10.17993/3ctecno.2021.specialissue7.61-75

Memon, A. H., Memon N, Memon, Z. A \& Hashmani A. A (2021c). GRM Buck Converter with High Input Power Factor. 3C Tecnología. Glosas de innovación aplicadas a la pyme. Edición Especial, May 2021, 143-155. https://doi.org/10.17993/3ctecno.2021. specialissue7.143-155

Memon, A. H., Memon, Z. A., Shaikh, N. N., Sahito, A. A., \& Hashmani, A. A. (2019a). Boundary conduction mode modified buck converter with low input current total harmonic distortion. Indian Fournal of Science and Technology, 12, 17. https://doi. org/10.17485/ijst/2019/v12i17/144613

Memon, A. H., Noonari, F. M., Memon, Z. A., Farooque, A., y Uqaili, M. A. (2020). AC/DC Critical Conduction Mode Buck-Boost Converter with Unity Power Factor. 3C Tecnología. Glosas de innovación aplicadas a la pyme. Edición Especial, Abril 2020, 93-105. http://doi.org/10.17993/3ctecno.2020

Memon, A. H., Shaikh, N. N., Kumar, M., \& Memon, Z. A. (2019b). Buck-buck/boost converter with high input power factor and non-floating output voltage. International 
Journal of Computer Science and Network Security, 19(4), 299-304. http://paper.ijcsns. org/07_book/201904/20190442.pdf

Memon, A. H., Yao, K., Ghen, Q., Guo,J., \& Hu, W. (2016). Variable-on-time control to achieve high input power factor for a CRM-integrated buck-flyback PFC converter. IEEE Transactions on Power Electronics, 32(7), 5312-5322. https://doi.org/10.1109/ TPEL.2016.2608839

Memon, A.H., Memon, M.A., Memon, Z.A. \& Hashmani, A.A. (2019c). Critical Conduction Mode Buck-Buck/Boost Converter with High Efficiency. 3C Tecnología. Glosas de innovación aplicadas a la pyme. Speciaal Issue, November 2019, 201-219. http:// dx.doi.org/10.17993/3ctecno.2019.specialissue3.201-219

Memon, A.H., Nizamani, M.O., Memon, A.A., Memon, Z.A. \& Soomro, A.M. (2019d). Achieving high input power factor for DCM Buck PFG converter by variable Duty-Cycle Control. 3C Tecnología. Glosas de innovación aplicadas a la pyme. Speciaal Issue, November 2019, 185-199. http://dx.doi.org/10.17993/3ctecno.2019. specialissue3.185-199

Memon, A.H., Pathan, A.A., Kumar, M. and Sahito, A., A J., \& Memon, Z.A (2019e). Integrated buck-flyback converter with simple structure and unity power factor. Indian Fournal of Science and Technology, 12, 17. https://doi.org/10.17485/ ijst/2019/v12i17/144612

Nagaraju, A., \& Krishnaveni, A. (2017). PSIM Simulation of Variable Duty Cycle Control DCM Boost PFC Converter To Achieve High Input Power Factor. International Research Journal of Engineering and Technology (IRJET), 4(3), 882-888. https: / / www.irjet. net/archives/V4/i3/IRJET-V4I3224.pdf

Nussbaumer, T., Raggl, K., \& Kolar, J. W. (2009). Design guidelines for interleaved single-phase boost PFG circuits. IEEE Transactions on Industrial Electronics, 56(7), 25592573. https:/ / doi.org/10.1109/TIE.2009.2020073

Praneeth, A. V.J. S., \& Williamson, S. S. (2018). A review of front end ac-dc topologies in universal battery charger for electric transportation. In 2018 IEEE Transportation 
Electrification Conference and Expo (ITEC) (pp. 293-298). IEEE. https://doi.org/10.1109/ ITEG.2018.8450186

Spiazzi, G., \& Buso, S. (2000). Power factor preregulators based on combined buckflyback topologies. IEEE transactions on Power Electronics, 15(2), 197-204. https://doi. org/10.1109/63.838091

Williamson, S. S., Rathore, A. K., \& Musavi, F. (2015). Industrial electronics for electric transportation: Current state-of-the-art and future challenges. IEEE Transactions on Industrial Electronics, 62(5), 3021-3032. https://doi.org/10.1109/TIE.2015.2409052

Yao, K., Ruan, X., Mao, X., \& Ye, Z. (2011). Variable-Duty-Cycle Control to Achieve High Input Power Factor for DCM Boost PFC Converter. IEEE Transactions On Industrial Electronics, 58(5), 1856-1865. https://doi.org/10.1109/TIE.2010.2052538

Yao, K., Zhou, X., Yang, F., Yang, S., Gao, G., \& Mao, G. (2017). Optimum third current harmonic during nondead zone and its control implementation to improve PF for DGM buck PFC converter. IEEE Transactions on Power Electronics, 32(12), 92389248. https://doi.org/10.1109/TPEL.2017.2657883 